\title{
Rekayasa Aplikasi Komputerisasi Sarana dan Prasarana Sekolah Dasar
}

\author{
Alfry Aristo J. Sinlae ${ }^{1 *}$, Frengky Tedy ${ }^{2}$, Emerensiana Ngaga ${ }^{3)}$, Paulina Aliandu ${ }^{4)}$ \\ 1,2,3,4 Program Studi Ilmu Komputer, Fakultas Teknik, Universitas Katolik Widya Mandira \\ 1*alfry.aj@unwira.ac.id, 2frengkytedy@unwira.ac.id, \\ ${ }^{3}$ emerensianangaga@unwira.ac.id, ${ }^{4}$ paulinaaliandu@unwira.ac.id
}

\begin{abstract}
XYZ Elementary School has problems in data collection of school inventory items, namely the recording process is still recorded in a logbook so that the number of items available is not updated in real-time if there are items borrowed, items repaired, or damaged goods. Also, the responsible officer must surround each room one by one to check and record goods resulting in a waste of time for data collection and inefficient. To solve the problems experienced by the school, a computerized application was engineered to process the data collection of inventory items to make it easier for officers to collect data so that performance would be more effective and efficient. The system development method used is the prototype method which consists of several stages, namely collecting information from customers, planning the system, and working on software prototypes, submitting prototype results to customers to be evaluated if there are problems, then the system will be revised so that it fits the needs. customer, if the revision is complete and has been accepted, the software is ready to be translated into hardware, performs a trial process, and various revisions before starting to be used. The application to be engineered is a web-based application using the PHP programming language version 7 which is combined with the Laravel version 5 framework, and the database uses MySQL, and the testing of this application uses black-box testing techniques. It is hoped that this application can facilitate the work of the person in charge of facilities and infrastructure in providing accurate and updated information regarding the availability of facilities and infrastructure at the school.
\end{abstract}

Keywords: Facilities and infrastructure; Web; Laravel

\section{PENDAHULUAN}

Di masa ini perkembangan teknologi informasi semakin pesat, teknologi informasi lahir dari pemikiran manusia untuk mempermudah seluruh aktivitas manusia. Aktivitas yang lazimnya memanfaatkan peranan teknologi informasi antara lain pengolahan data keuangan, pengolahan data penjualan dan pembelian, pengolahan data kepegawaian, dan pengolahan data inventarisasi barang.

Riset ini membahas tentang pentingnya inventarisasi dalam suatu lembaga pendidikan, dikarenakan dalam setiap lembaga pendidikan atau sebuah instansi selalu memiliki keterkaitan dengan proses pengelolaan data inventaris yang dimiliki oleh lembaga atau instansi tersebut. Hal itu bersifat sangat penting, demi menjaga agar aset tetap aman. Oleh karena itu, dibutuhkan suatu aplikasi komputerisasi inventaris dalam mengelola data tersebut. Inventarisasi barang merupakan pencatatan data yang hubungannya dengan barang atau aset di dalam sebuah instansi. Umumnya kegiatan dalam inventarisasi barang adalah pencatatan pengadaan barang, penempatan, dan pemeliharaan.

Riset ini mengambil studi kasus yang ada pada Sekolah Dasar (SD) XYZ, dimana kegiatan inventarisasi dan pengelolaan barangnya masih kurang efektif. Permasalahan yang terdapat dari kegiatan inventarisasi barang yang dilaksanakan pada SD XYZ yaitu petugas yang bertanggung jawab dalam mengelola sarana dan prasarana masih menggunakan cara konvensional dalam pendataan inventaris yakni dicatat dalam logbook 
atau buku khusus untuk inventaris. Permasalahan lainnya jika pencatatan inventaris dalam skala besar maka logbook yang dibutuhkan juga banyak belum lagi resiko hilangnya data inventaris. Dalam hal pencatatan inventaris juga tidak adanya identitas aset atau barang yang menyebabkan kesulitan pendeteksian aset yang sedang rusak dan mempengaruhi proses pengecekan stok barang.

Dengan perkembangan teknologi informasi yang sudah maju, diharapkan dapat membantu kegiatan mengelola aset yang lebih mudah, sehingga bagian sarana prasarana SD XYZ tidak perlu lagi mencatat secara konvensional lagi dan mengarsipkan berkas-berkas yang cukup membuat penuh ruangan penyimpanan dan sukar ditemukan, namun cukup duduk di depan monitor untuk mengakses aplikasi komputerisasi ini sehingga mendapatkan data dan informasi tentang aset yang dimiliki dari pengadaan barang, penyaluran barang, informasi keadaan barang dan pengawasan serta pengendalian barang. Dengan demikian kegiatan pengelolaan aset akan terasa mudah dan lebih efisien.

\section{KAJIAN LITERATUR}

Riset-riset sebelumnya yang terkait dengan pembahasan aplikasi inventaris, antara lain:

Riset yang berjudul "Analisis dan Implementasi Sistem Aplikasi Inventory Items berbasis Web menggunakan Framework Codeigniter", menghasilkan aplikasi inventaris berbasis web yang menggunakan kerangka kerja Codeigniter untuk membantu perusahaan dalam mengelola data inventaris seperti pemasukan data barang, rusak, kepemilikan barang, pengadaan barang, barang rusak, penyempurnaan barang dan pergerakan barang [1].

Riset selanjutnya yang berjudul "Pengembangan Aplikasi Pengelolaan Inventaris Barang berbasis Web di Sekolah Tinggi Teknologi Garut", menghasilkan pengembangan aplikasi pengelolaan inventaris barang berbasis web di Sekolah Tinggi Teknologi Garut yang dapat membantu dalam pengelolaan barang inventaris sehingga pembuatan laporan data barang inventaris menjadi lebih mudah [2].

Riset selanjutnya yang berjudul "Perancangan Sistem Informasi Inventaris Barang pada Sekolah SMA Negeri 4 Pematangsiantar", menghasilkan implementasi dari sistem informasi inventaris ini adalah pencatatan data inventaris serta pembuatan laporan inventaris lebih mudah untuk dilakukan dan dengan adanya sistem informasi inventaris barang ini, pekerjaan pendataan inventaris barang pada SMA Negeri 4 Pematangsiantar sudah dapat dilakukan dengan lebih cepat dan akurat [3].

Riset selanjutnya yang berjudul "Aplikasi Inventaris Barang pada MTS Nurul Islam Dumai menggunakan PHP dan Mysql" menghasilkan implementasi dari sistem informasi inventaris ini adalah pencatatan data inventaris serta pembuatan laporan inventaris lebih mudah untuk dilakukan. Dengan adanya sistem informasi inventaris barang ini, pekerjaan pendataan inventaris barang pada MTS Nurul Islam Kota Dumai sudah dapat dilakukan dengan lebih cepat dan akurat [4].

Riset berikutnya yang berjudul "Prototipe Aplikasi Inventaris Barang pada Biro Administrasi Umum STMIK Atma Luhur" menghasilkan prototype/prototipe untuk membangun sebuah aplikasi inventaris yang dapat merekam dan menyusun data barang dengan teratur [5].

Berdasarkan riset-riset yang telah dibahas sebelumnya, originalitas riset ini terletak pada rekayasa aplikasi yang menggunakan framework laravel sebagai kerangka kerja dalam merekayasa aplikasi ini. Selain itu aplikasi ini dapat menjadi model untuk komputerisasi data-data inventaris sarana dan prasarana pada sekolah-sekolah lainnya yang terletak di kota Kupang dan sekitarnya.

Dasar teori yang digunakan dalam riset ini, antara lain:

Inventaris dalam Kamus Besar Bahasa Indonesia (KBBI) online memiliki arti daftar yang memuat semua barang milik kantor (sekolah, perusahaan, kapal, dan 
sebagainya) yang dipakai dalam melaksanakan tugas [6]. Barang inventaris sekolah adalah semua barang milik negara (yang dikuasai sekolah) baik yang diadakan/dibeli melalui dana dari pemerintah, dasar pengenaan pajak (DPP) maupun diperoleh sebagai pertukaran, hadiah atau hibah serta hasil usaha pembuatan sendiri di sekolah guna menunjang kelancaran proses belajar mengajar [7].

Tiap sekolah wajib menyelenggarakan pencatatan atau pendaftaran barangbarang milik sekolah ke dalam suatu daftar inventaris barang secara tertib dan teratur menurut ketentuan dan tata cara yang berlaku atau melakukan inventarisasi barang milik negara yang dikuasai/diurus oleh sekolah masing-masing secara teratur, tertib dan lengkap. Kepala sekolah melakukan dan bertanggung jawab atas terlaksananya inventarisasi fisik dan pengisian daftar inventaris barang milik negara yang ada di sekolahnya [7].

Pengertian sarana dan prasarana menurut Ketentuan Umum Permendiknas (Peraturan Menteri Pendidikan Nasional) No. 24 Tahun 2007, yaitu: sarana adalah perlengkapan pembelajaran yang dapat dipindah-pindah, sedangkan prasarana adalah fasilitas dasar untuk menjalankan fungsi sekolah/madrasah. Sarana pendidikan antara lain gedung, ruang kelas, meja, kursi serta alat-alat media pembelajaran. Sedangkan yang termasuk prasarana antara lain seperti halaman, taman, lapangan, jalan menuju sekolah dan lain-lain [8].

Laravel adalah sebuah model view controller (MVC) web development framework yang didesain untuk meningkatkan kualitas perangkat lunak dengan mengurangi biaya pengembangan dan perbaikan serta meningkatkan produktifitas pekerjaan dengan sintak yang bersih dan fungsional yang dapat mengurangi banyak waktu untuk implementasi [9].

Lavarel merupakan framework dengan versi PHP yang up to date, karena Laravel mensyaratkan PHP versi 5.3 keatas. Laravel merupakan framework PHP yang menekankan pada kesederhanaan dan fleksibilitas pada desainnya [10].

Laravel memberikan keterbaruan alat untuk berinteraksi dengan database disebut dengan migration. Dengan migration, pengembang dapat dengan mudah melakukan modifikasi sebuah database pada sebuah platform secara independen karena implementasi skema database direpresentasikan dalam sebuah class [11].

Migration dapat berjalan pada beberapa basis data yang telah didukung Laravel (MySQL, PostgreSQL, MSSQL, dan SQLITE) dan untuk implementasi active record pada laravel disebut eloquent yang menggunakan standard modern OOP. Laravel juga memberikan sebuah command line interface yang disebut dengan artisan, pengembang dapat berinteraksi dengan aplikasi untuk sebuah aksi seperti migrations, testing, atau membuat controller dan model. Selain itu, laravel juga memiliki blade template engine yang memberikan estetika dan kebersihan kode pada view secara parsial [11].

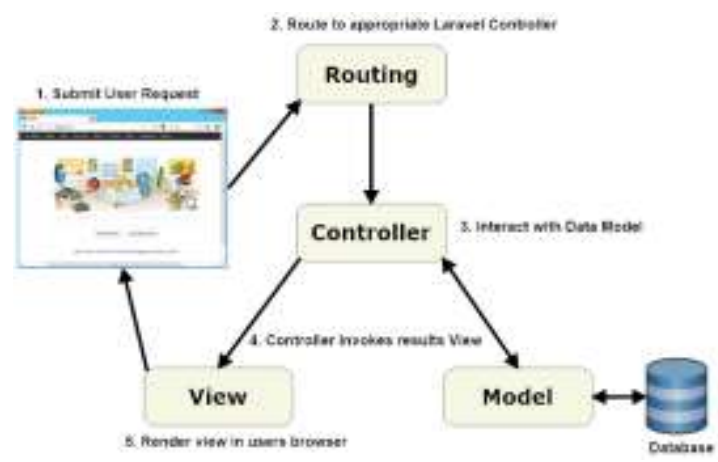

Gambar 1. Arsitektur Laravel [12]

\section{METODE PENELITIAN}

Tahapan penelitian yang digunakan dalam penelitian ini menggunakan metode pengembangan sistem, yaitu model prototype. Model prototype merupakan suatu paradigma baru dalam metode pengembangan perangkat lunak dimana metode ini tidak hanya sekedar evolusi dalam dunia pengembangan perangkat lunak, tetapi juga merevolusi metode pengembangan perangkat lunak yang lama yaitu sistem sekuensial yang biasa dikenal dengan nama SDLC atau waterfall development model. 
Dalam model prototype, prototype dari perangkat lunak yang dihasilkan kemudian dipresentasikan kepada pelanggan, dan pelanggan tersebut diberikan kesempatan untuk memberikan masukan sehingga perangkat lunak yang dihasilkan nantinya betul-betul sesuai dengan keinginan dan kebutuhan pelanggan.

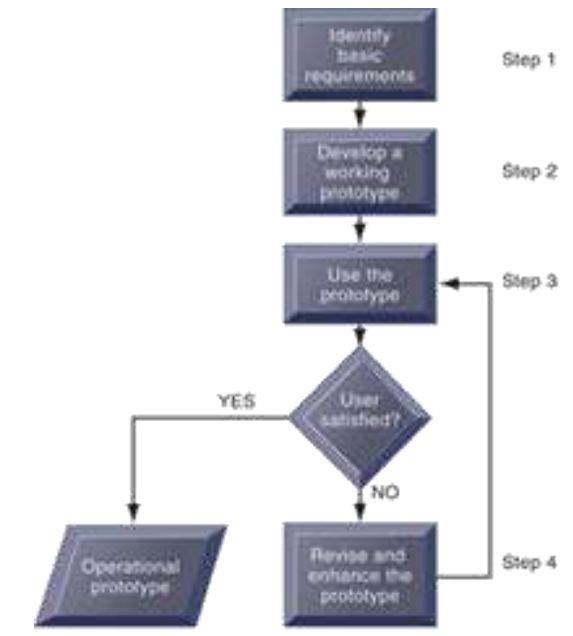

Gambar 2. Tahapan Penelitian Mengadopsi Model Prototype (Laudon \& Laudon, 2014)

Tahapan dalam model prototype dapat dijelaskan sebagai berikut:

1. Tahap pertama, pengembang aplikasi melakukan pengumpulan informasi dari pelanggan untuk mencari tahu apa yang diinginkan oleh pelanggan;
Pada tahap ini dilakukan survey dan wawancara ke pihak terkait untuk mengetahui masalah-masalah yang terjadi di sekolah tersebut sehingga diperoleh informasi untuk pengelolaan inventaris sarana dan prasarana dibutuhkan empat orang yang berperan sebagai pengguna aplikasi, yaitu: admin, penanggung jawab ruangan, pembimbing (wali kelas) dan guru biasa (bukan penanggung jawab ruangan).

2. Tahap kedua, pengembang aplikasi merencanakan sistem dan mengerjakan purwarupa perangkat lunak;

Pada tahap ini dirancang proses kerja berdasarkan peran dari setiap pengguna aplikasi. Proses kerja tersebut digambarkan dalam bentuk diagram use case, diagram sequence dan diagram activity. Diagram use case berfungsi untuk menjelaskan peran dari setiap actor atau pengguna aplikasi dalam mengoperasikan aplikasi yang dibuat, selanjutnya diagram sequence berfungsi untuk menjelaskan setiap proses-proses yang terjadi di dalam aplikasi secara berurutan, sedangkan diagram activity berfungsi untuk menjelaskan setiap aktivitas/kejadian yang terjadi pada aplikasi.

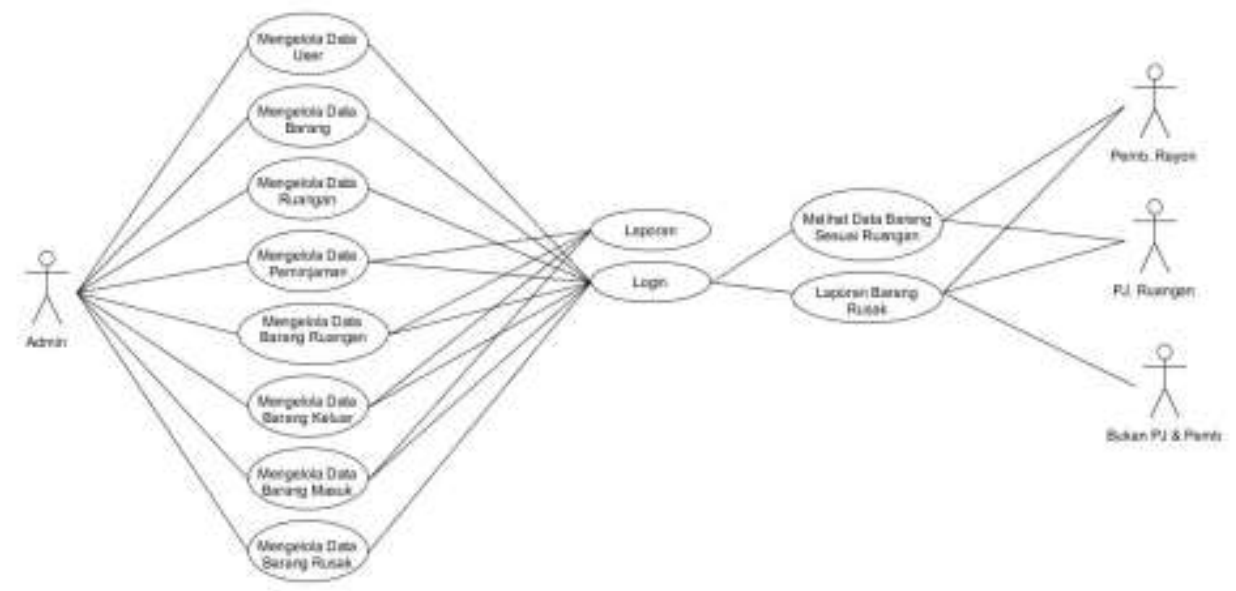

Gambar 3. Diagram Use Case

Pada gambar 3 terlihat bahwa peran admin memiliki andil yang besar dalam aplikasi. Admin dapat mengelola data user, data barang, data ruangan, data peminjaman, data barang dalam ruangan, data barang masuk, data barang keluar, data barang rusak dan mencetak laporan. Sedangkan ketiga pengguna lainnya hanya dapat melihat data barang sesuai ruangan dan laporan barang rusak. 


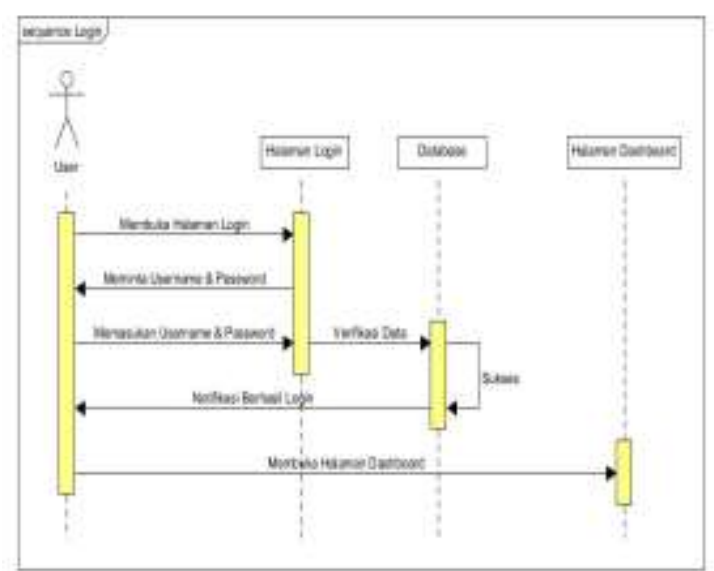

Gambar 4. Diagram Sequence Login

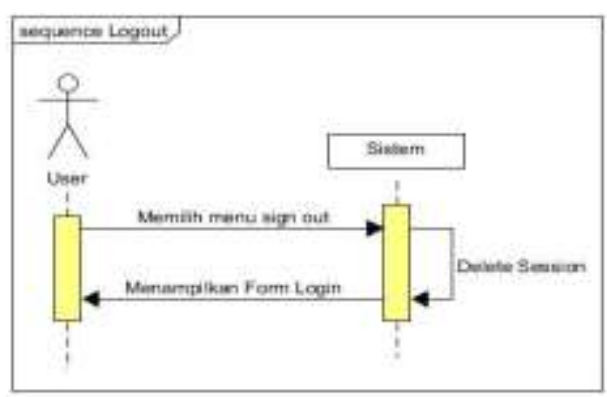

Gambar 5. Diagram Sequence Logout

Gambar 4 dan 5 menjelaskan urutan kejadian dalam melakukan proses masuk ke dalam aplikasi (login) dan keluar dari aplikasi (logout).

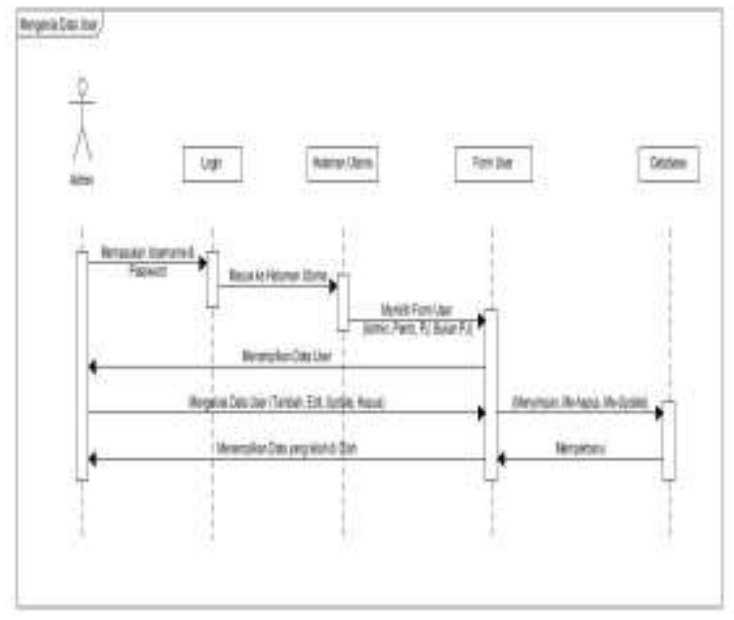

Gambar 6. Diagram Sequence Kelola Data User

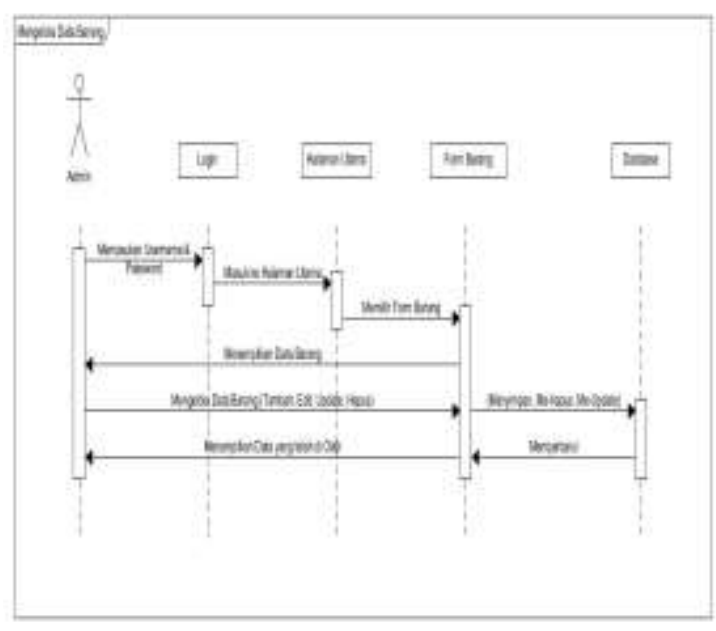

Gambar 7. Diagram Sequence Kelola Data Barang

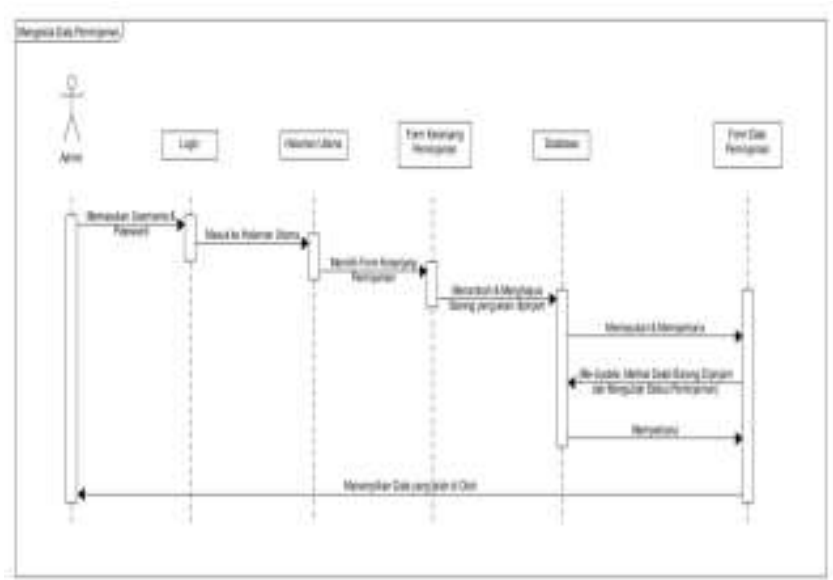

Gambar 8. Diagram Sequence Kelola Data Peminjaman

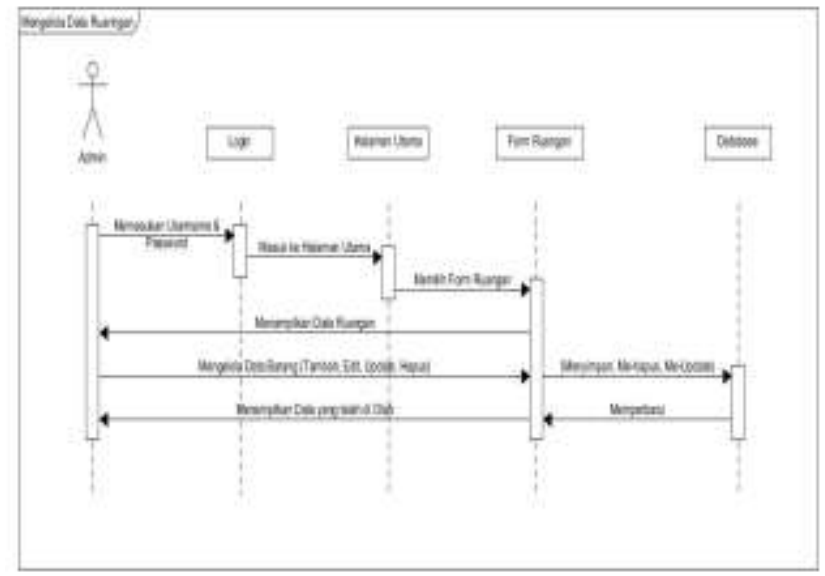

Gambar 9. Diagram Sequence Kelola Data Ruangan 


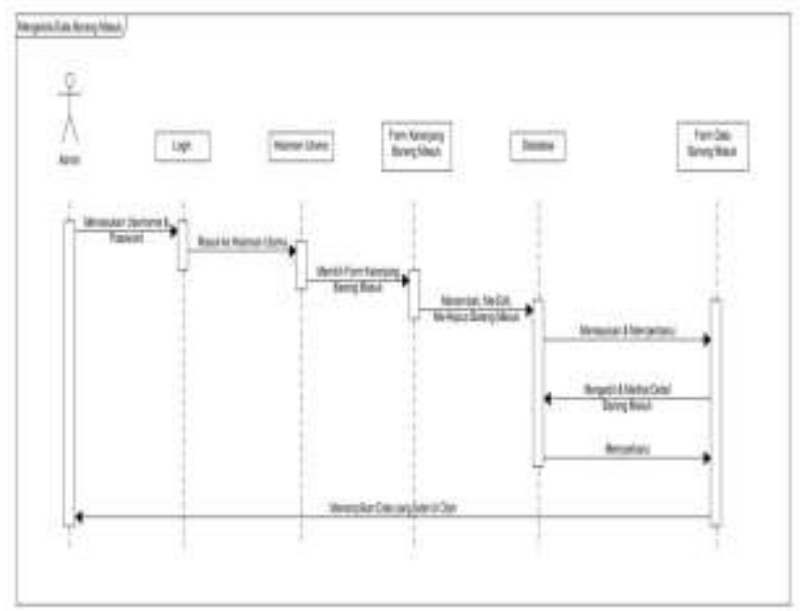

Gambar 10. Diagram Sequence Kelola Data Barang Masuk

Gambar 6, 7, 8, 9 dan 10 merupakan urutan proses yang dilakukan oleh admin setelah berhasil masuk ke dalam aplikasi dalam melakukan pengelolaan data-data baik menambahkan data baru, mengubah dan memperbaharui data, maupun menghapus data.
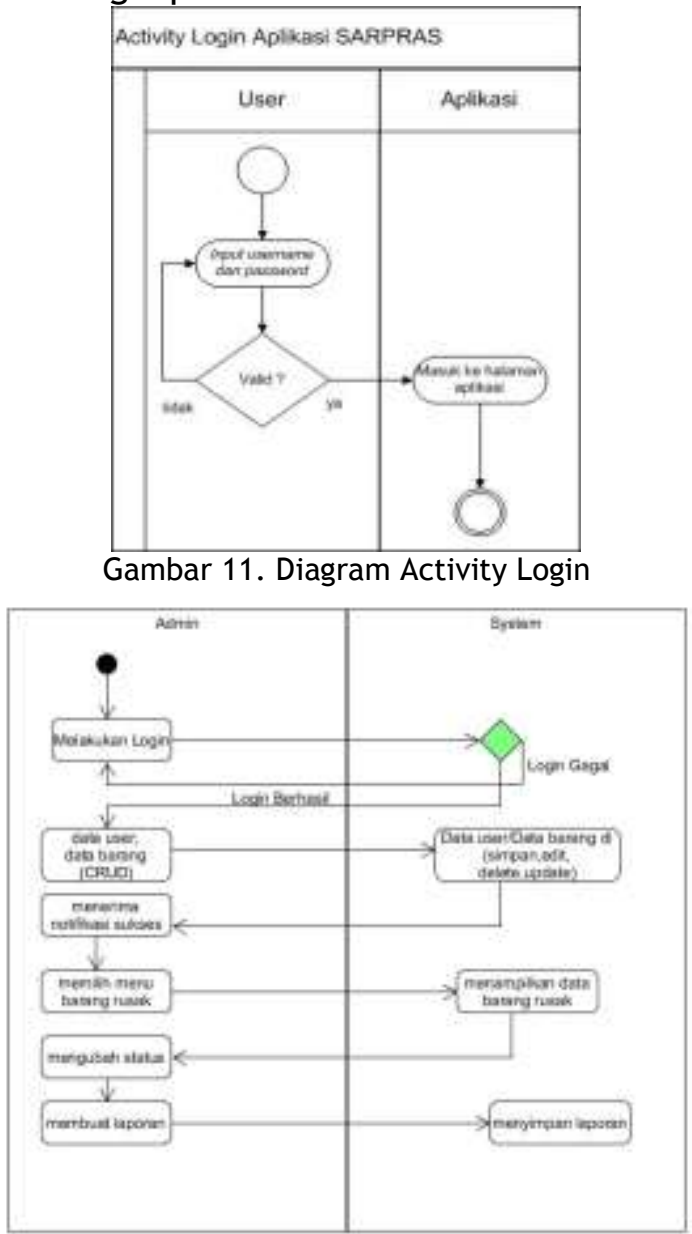

Gambar 12. Diagram Activity Admin

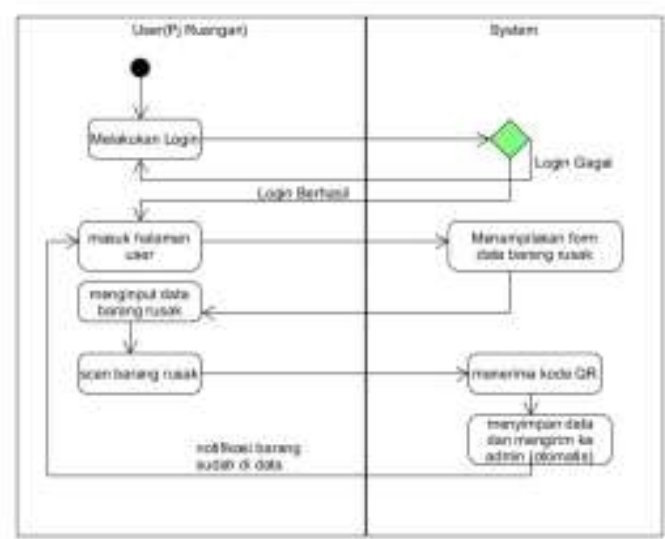

Gambar 12. Diagram Activity Penanggung jawab Ruangan

Gambar 11, 12 dan 13 merupakan urutan aktivitas/kejadian yang dilakukan user/pengguna untuk mengoperasikan aplikasi ini. Diawali dengan melakukan login sesuai dengan perannya masing-masing terlihat ditunjukkan pada gambar 11. Jika login sebagai admin maka dapat melakukan aktivitas create, retrieve, update dan delete (CRUD) data seperti terlihat pada gambar 12. Sedangkan jika login sebagai penanggung jawab ruangan maka hanya dapat melakukan aktivitas memasukkan data barang rusak dan melihat laporan barang rusak.

3. Tahap ketiga, pengembang aplikasi menyerahkan hasil purwarupa kepada pelanggan untuk dievaluasi apabila terdapat permasalahan, maka akan direvisi aplikasi tersebut hingga benarbenar sesuai dengan kebutuhan pelanggan;

Pada tahap ini dilakukan perbaikanperbaikan yang terdapat pada perancangan proses sebelumnya jika ditemukan ketidaksesuaian. Apabila sudah sesuai dengan kebutuhan pelanggan maka dirancang struktur database yang berfungsi untuk perancangan basis data yang digunakan dalam aplikasi. 


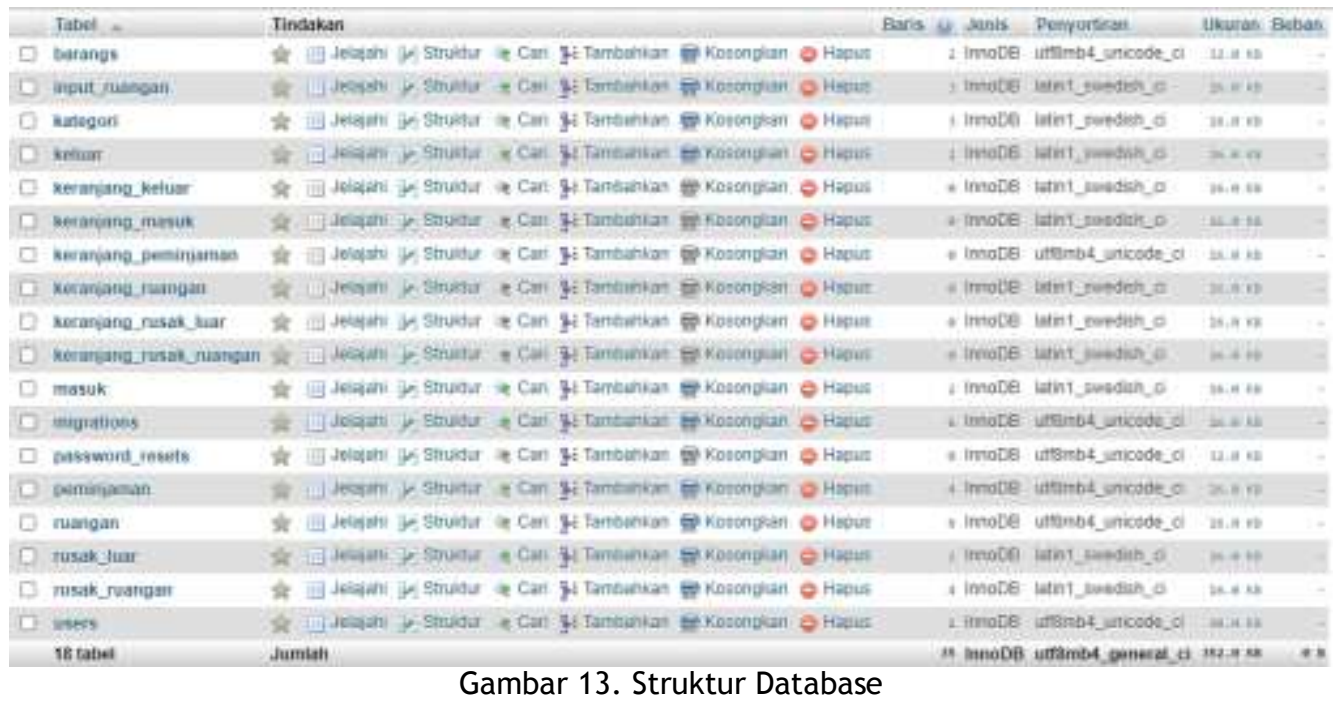

4. Tahap keempat, jika revisi selesai dan telah diterima, perangkat lunak telah siap diterjemahkan ke dalam perangkat keras dan melakukan proses uji coba dan berbagai revisi sebelum mulai dapat digunakan.

Pada tahap ini dilakukan rekayasa aplikasi menggunakan bahasa pemrograman PHP versi 7, database penyimpanan data menggunakan MySQL dengan engine InnoDB serta memanfaatkan kerangka kerja (framework) Laravel. Hasil dari tahapan ini dibahas pada bagian hasil dan pembahasan.

\section{HASIL DAN PEMBAHASAN}

Implementasi hasil merupakan luaran dari rekayasa aplikasi berupa tampilan antar muka yang digunakan untuk memudahkan pengguna dalam mengakses aplikasi komputerisasi ini. Berikut merupakan tampilan antar muka dari beberapa form, antara lain:

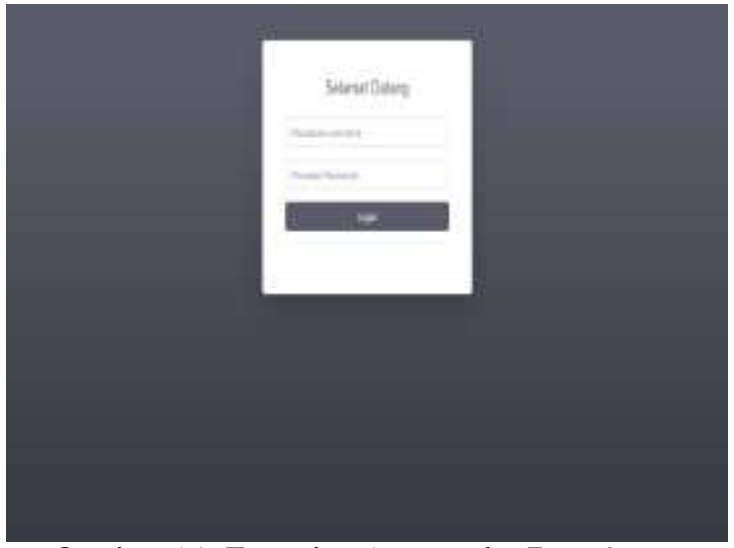

Gambar 14. Tampilan Antarmuka Form Login

Pertama kali aplikasi dijalankan akan dihadapkan dengan tampilan antar muka login seperti terlihat pada gambar 14, sehingga pengguna diminta untuk memasukkan usename dan password supaya dapat mengakses modul-modul yang terdapat di dalam aplikasi. 


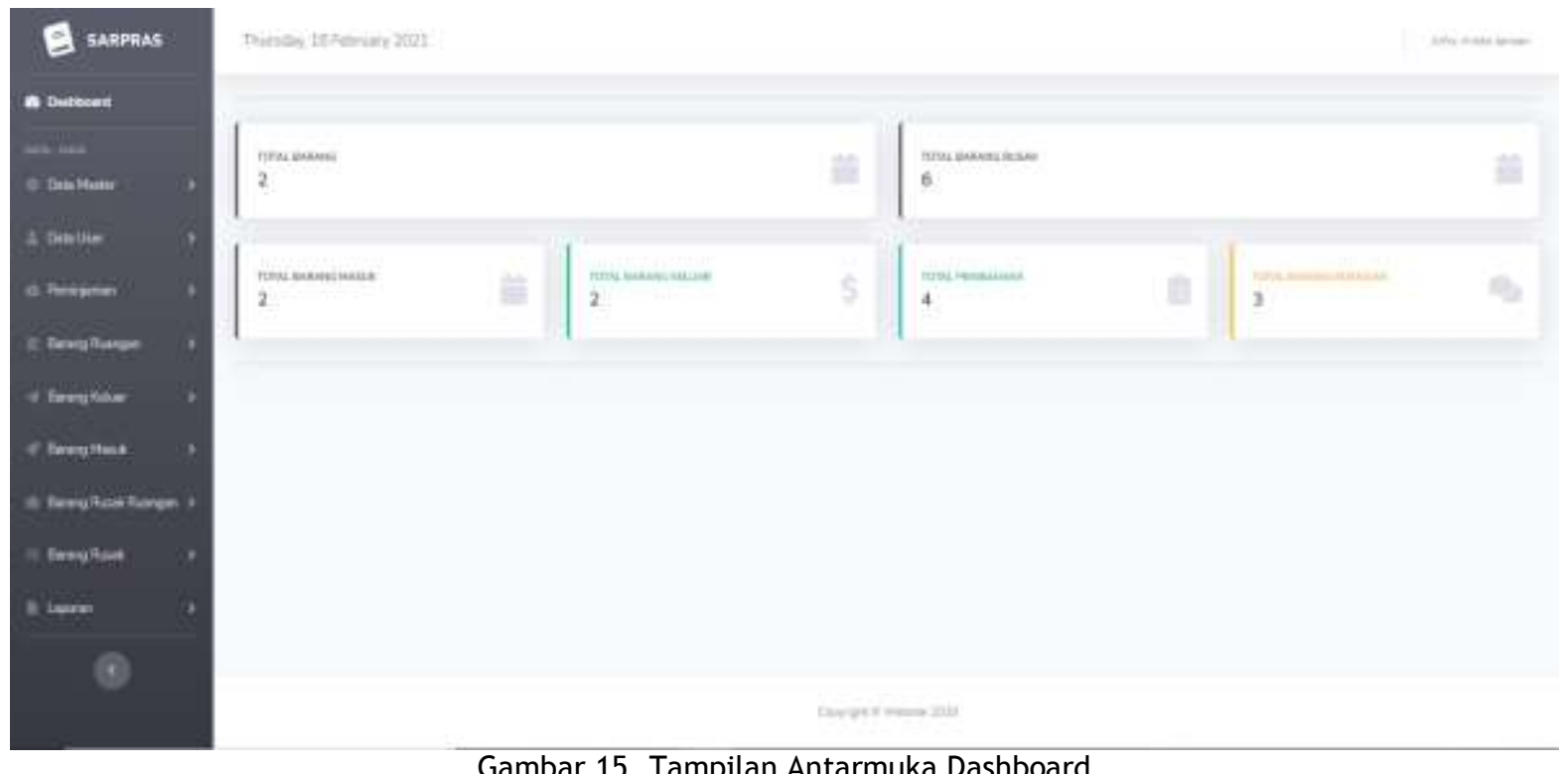

Gambar 15. Tampilan Antarmuka Dashboard

Gambar 15 merupakan tampilan antar muka dashboard yang ditampilkan jika admin berhasil login ke dalam aplikasi ini. Tampilan antar muka ini berisikan notifikasi total barang, total barang rusak, total barang masuk, total barang keluar, total peminjaman dan total barang ruangan.
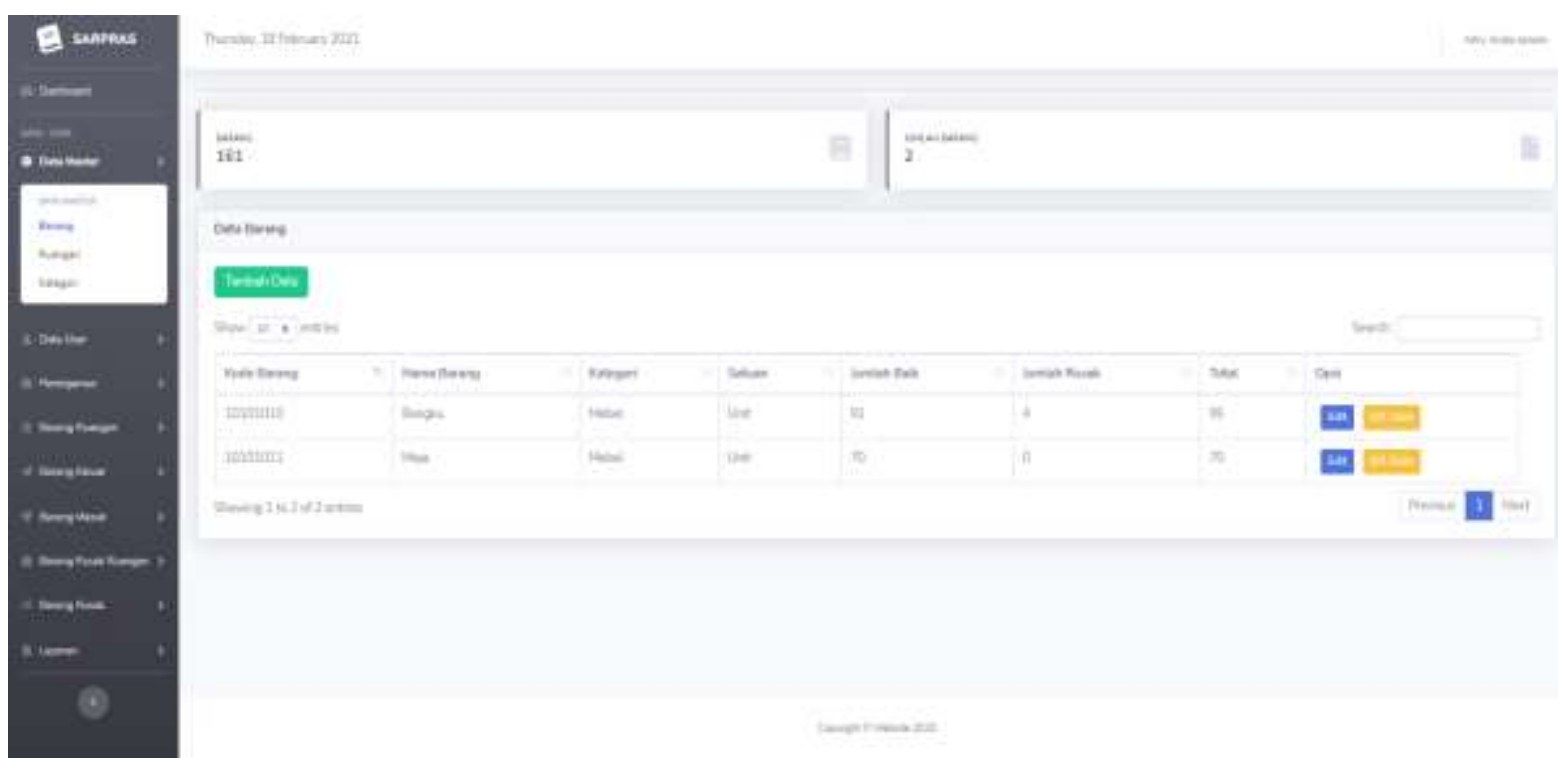

Gambar 16. Tampilan Antarmuka Menu Data Master Barang

Gambar 16 merupakan tampilan antar muka menu data master barang yang berisikan notifikasi barang dan jumlah barang. Selain itu terdapat tombol tambah data untuk menambahkan data barang, tombol edit untuk mengubah data serta tombol QR code untuk mendapatkan kode QR dari barang yang ditambahkan.

Gambar 17 berikut merupakan tampilan antar muka menu laporan barang ruangan yang berisikan kode ruangan, nama barang, jumlah barang dalam kondisi baik, jumlah barang dalam kondisi rusak dan total barang. Menu ini juga memiliki tombol export yang berfungsi untuk melakukan export laporan dalam bentuk file excel. Pertama kali admin memilih ruangan yang akan ditampilkan laporannya kemudian menekan tombol submit supaya laporan dari ruangan tersebut ditampilkan. Jika ingin mencetak laporan tersebut maka memilih tombol export yang kemudian laporan tersebut disajikan dalam bentuk excel. 

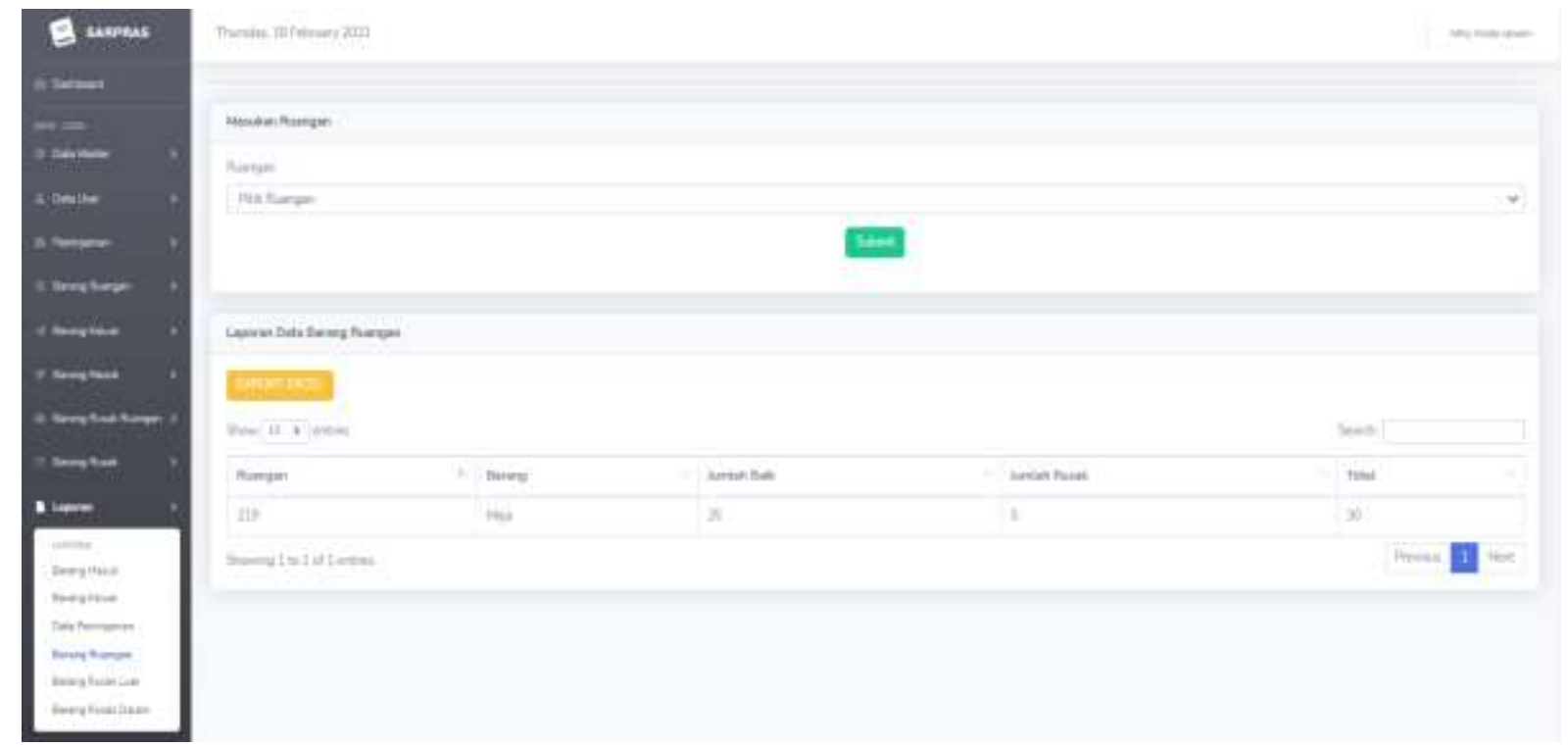

Gambar 17. Tampilan Antarmuka Menu Laporan Barang Ruangan

Pengujian aplikasi merupakan langkah yang dilakukan untuk melakukan uji coba seluruh modul dan operasi yang terdapat pada aplikasi. Teknik pengujian yang dilakukan menggunakan teknik pengujian Black Box. Black box merupakan sebuah metode yang digunakan untuk menemukan kesalahan dan mendemonstrasikan fungsional aplikasi saat dioperasikan, apakah input diterima dengan benar dan output yang dihasilkan telah sesuai dengan yang diharapkan.

Tabel 1. Teknik Pengujian Black Box

\begin{tabular}{|c|c|c|}
\hline Langkah Uji & $\begin{array}{l}\text { Output yang } \\
\text { diharapkan }\end{array}$ & $\begin{array}{c}\text { Output dari } \\
\text { pengujian }\end{array}$ \\
\hline $\begin{array}{l}\text { Username dan } \\
\text { Password } \\
\text { sesuai }\end{array}$ & $\begin{array}{l}\text { Diterima oleh } \\
\text { aplikasi } \\
\text { sehingga dapat } \\
\text { mengakses } \\
\text { aplikasi }\end{array}$ & $\begin{array}{l}\text { Sesuai dengan } \\
\text { yang } \\
\text { diharapkan }\end{array}$ \\
\hline $\begin{array}{l}\text { Username dan } \\
\text { Password salah } \\
\text { satunya salah }\end{array}$ & $\begin{array}{l}\text { Tidak diterima } \\
\text { oleh aplikasi } \\
\text { sehingga gagal } \\
\text { masuk }\end{array}$ & $\begin{array}{l}\text { Sesuai dengan } \\
\text { yang } \\
\text { diharapkan }\end{array}$ \\
\hline $\begin{array}{l}\text { Menambahkan } \\
\text { data pada } \\
\text { setiap modul } \\
\text { jika ada salah } \\
\text { satu isian yang } \\
\text { kosong }\end{array}$ & $\begin{array}{l}\text { Tampil } \\
\text { peringatan } \\
\text { untuk } \\
\text { melakukan } \\
\text { pengisian pada } \\
\text { isian yang } \\
\text { kosong }\end{array}$ & $\begin{array}{l}\text { Sesuai dengan } \\
\text { yang } \\
\text { diharapkan }\end{array}$ \\
\hline
\end{tabular}

\begin{tabular}{|c|c|c|}
\hline $\begin{array}{l}\text { Mengubah data } \\
\text { pada setiap } \\
\text { modul jika ada } \\
\text { salah satu isian } \\
\text { yang kosong }\end{array}$ & $\begin{array}{l}\text { Tampil } \\
\text { peringatan } \\
\text { untuk } \\
\text { melakukan } \\
\text { pengisian pada } \\
\text { isian yang } \\
\text { kosong }\end{array}$ & $\begin{array}{l}\text { Sesuai dengan } \\
\text { yang } \\
\text { diharapkan }\end{array}$ \\
\hline $\begin{array}{l}\text { Menekan } \\
\text { tombol submit } \\
\text { tanpa memilih } \\
\text { salah satu isian } \\
\text { pada menu } \\
\text { laporan }\end{array}$ & $\begin{array}{l}\text { Laporan tidak } \\
\text { ditampilkan } \\
\text { dan tombol } \\
\text { export tidak } \\
\text { muncul }\end{array}$ & $\begin{array}{l}\text { Sesuai dengan } \\
\text { yang } \\
\text { diharapkan }\end{array}$ \\
\hline $\begin{array}{l}\text { Menekan } \\
\text { tombol submit } \\
\text { setelah } \\
\text { memilih salah } \\
\text { satu isian pada } \\
\text { menu laporan }\end{array}$ & $\begin{array}{l}\text { Laporan } \\
\text { ditampilkan } \\
\text { dan tombol } \\
\text { export muncul }\end{array}$ & $\begin{array}{l}\text { Sesuai dengan } \\
\text { yang } \\
\text { diharapkan }\end{array}$ \\
\hline
\end{tabular}

\section{KESIMPULAN}

Kesimpulan yang dapat ditarik berdasarkan hasil dan pembahasan, antara lain:

Aplikasi dapat digunakan dengan baik setelah dilakukan uji coba secara black box dimana semua fitur dan operasi yang terdapat di dalamnya dapat diakses tanpa adanya gangguan.

Aplikasi dapat melakukan pencatatan inventaris yang terkomputerisasi sehingga memudahkan penanggung jawab dalam pencatatan dan pendistribusian inventaris sekolah dan dapat menghasilkan laporan data inventaris beserta distribusi dan status secara real time dan up to date. 


\section{UCAPAN TERIMA KASIH}

Penulis menyampaikan limpah terima kasih kepada Lembaga Penelitian dan Pengabdian Kepada Masyarakat (LPPM) Universitas Katolik Widya Mandira yang telah mendanai sepenuhnya penelitian ini melalui Hibah Penelitian UNWIRA Tahun Pelaksanaan 2020.

\section{REFERENSI}

[1] A. Rahman, "Analisis dan Implementasi Sistem Aplikasi Inventory Items Berbasis Web Menggunakan Framework Codeigniter," Al Ulum Sains dan Teknol., vol. 2, no. 1, pp. 35-38, 2016, doi: http://dx.doi.org/10.31602/ajst.v2i1 .650 .

[2] Ridwan Setiawan, A. Ikhwana, and E. Rahayu, "Pengembangan Aplikasi Pengelolaan Inventaris Barang Berbasis Web Di Sekolah Tinggi Teknologi Garut," J. Algoritm., 2017.

[3] V. M. M. Siregar, "Perancangan Sistem Informasi Inventaris Barang Pada Sekolah SMA Negeri 4 Pematangsiantar," IT J. Res. Dev., 2018, doi: 10.25299/itjrd.2018.vol3(1).1899.

[4] M. S. Novendri, A. Saputra, and C. E. Firman, "Aplikasi Inventaris Barang Pada Mts Nurul Islam Dumai Menggunakan Php Dan Mysql," Lentera Dumai, 2019.

[5] S. Sujono, M. Maxrizal, and A. A. A. E. Helmud, "Prototipe Aplikasi Inventaris Barang pada Biro Administrasi Umum STMIK Atma Luhur," in Sensitif 2019 (Seminar Nasional Sistem Informasi dan Teknik Informatika), 2019, pp. 9-14, [Online]. Available: https://ejurnal.dipanegara.ac.id/ind ex.php/sensitif/article/view/307/271

[6] K. P. dan K. R. I. Badan Pengembangan dan Pembinaan Bahasa, "Inventaris," KBBI Online, 2016.

https://kbbi.kemdikbud.go.id/entri/i nventaris (accessed Apr. 12, 2020).

[7] AsikBelajar.Com, "Pengertian, Tujuan dan Manfaat Inventarisasi Sarana dan
Sarana Pendidikan," AsikBelajar.Com, 2016.

https: / /www.asikbelajar.com/penger tian-tujuan-manfaat-inventarisasi-

sarana-prasarana-pendidikan/

(accessed Apr. 06, 2020).

[8] Peraturan Menteri Pendidikan Nasional Republik Indonesia, Standar Sarana Dan Prasarana Untuk Sekolah Dasar/Madrasah Ibtidaiyah (SD/MI), Sekolah Menengah Pertama/Madrasah Tsanawiyah (SMP/MTs), Dan Sekolah Menengah Atas/Madrasah Aliyah (SMA/MA). Indonesia, 2007.

[9] H. D. P. Bagas Prakoso Widodo, "Perancangan Aplikasi Pencarian Layanan Kesehatan Berbasis HTML 5 Geolocation," J. Sist. Komput., vol. 6, no. 1, pp. 44-51, 2016, [Online]. Available:

https://jsiskom.undip.ac.id/index.ph $\mathrm{p} / \mathrm{jsk} /$ article/view/108/71.

[10] D. Naista, Bikin Framework PHP Sendiri dengan Teknik OOP \& MVC, Cetakan Pe. Yogyakarta: CV. LOKOMEDIA, 2016.

[11] Farizan Luthfi, “Penggunaan Framework Laravel Dalam Rancang Bangun Modul Back-End Artikel Website Bisnisbisnis.ID," JISKA (Jurnal Inform. Sunan Kalijaga), vol. 2, no. 1, pp. 34-41, 2017, [Online]. Available: http://ejournal.uinsuka.ac.id/saintek/JISKA/article/dow nload/21-05/1059.

[12] C. Shekhar, "General architecture of Laravel based application," CuteHits.com, 2017. http://www.cutehits.com/ (accessed Jun. 06, 2020).

[13] Sinlae, A. A. J. (2019). Komputerisasi Surat Perintah Perjalanan Dinas (SPPD) Pada Kantor Dinas Peternakan Provinsi Nusa Tenggara Timur Berbasis Web. Patria Artha Technological Journal, 3(2), 60-69.

[14] Tahir, T. B., Apriyadi, M., Rais, M., \& Syarif, I. (2020). Sistem Informasi Encrypt Dan Decrypt Dengan Algoritma AES Menggunakan Framework Laravel. Patria Artha Technological Journal, 4(1), 41-46. 